УДК 656.025.4:681.3

\title{
ВАНТАЖНІ ПЕРЕВЕЗЕННЯ В МІЖНАРОДНОМУ СПОЛУЧЕННІ ПРИ ЗАСТОСУВАННІ ЗАСОБІВ ІНФОРМАТИЗАЦІЇ
}

К-т техн. наук Д.В. Шумик, магістранти Д.О. Редіна, Т.М. Лавріненко

ГРУЗОВЫЕ ПЕРЕВОЗКИ В МЕЖДУНАРОДНОМ

СООБЩЕНИИ ПРИ ИСПОЛЬЗОВАНИИ СРЕДСТВ ИНФОРМАТИЗАЦИИ

К-т техн. наук Д.В. Шумик, магистранты Д.О. Редина , Т.М.Лавриненко

\section{INTERNATIONAL FREIGHT TRANSPORTATION UNDER INFORMATION SYSTEM DEVELOPMENT}

Cand. of techn. sciences. D.V. Shumyk, master student D.O.Redina, T.M.Lavrinenko

В даній роботі були представлені особливості та можливості удосконалення експлуатаційної роботи залізничної станції в умовах інформатизації за допомогою автоматизованої системи «АСК ВП УЗ - С». Завдяки можливості інтегрування «АСК ВП

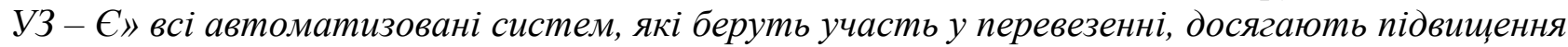
швидкості отримання, обробки, аналізу, відправки, та при необхідності корегування

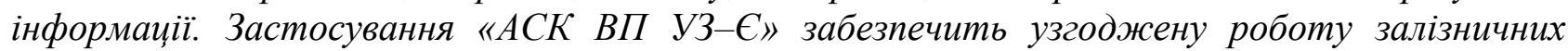
станцій, митних органів, та служб руху залізниці.

Ключові слова: інформатизація, удосконалення експлуатаційної роботи, оптимізація у реальному часі управлінських рішень, модернізачія, впровадження інформаційних систем.

В данной работе были представлены особенности $u$ возможности усовершенствования эксплуатаџионной работы железнодорожной станщии в условиях информатизащии с помощью автоматизированной системы «АСК ВП УЗ - Е». Благодаря

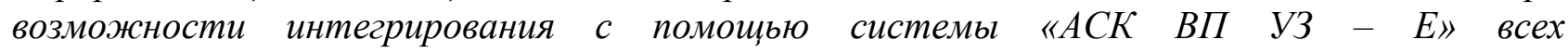


автоматизированных систем, участвующих в перевозке, ускоряется процесс получения, обработки, анализа, отправки, и при необходимости корректировки информации. Применение «АСК ВП УЗ -Е» обеспечит согласованную работу железнодорожных станщий, таможенных органов, и служб движения железной дороги.

Ключевые слова: информатизаџия, усовершенствование эксплуатационной работы, оптимизачия в реальном времени управленческих решений, модернизация, внедрение информационных систем.

The research deals with peculiarities and possibilities to improve railway station operation under information system development with the United freight transportation control system of Ukrzaliznytsia (ACK ВП УЗ-E) which helps to integrate all automated systems involved in the transportation process, improve the process of receiving, processing, analyzing, transferring and, if required, correcting the information. The system shall provide coordinated operation of railway stations, customs bodies and railway transportation departments.

Keywords: information system development, improved operation, real-time optimization of managerial decisions, modernization, implementation of information systems.

Вступ. Вступ України до міжнародних транспортних організацій та структур, ратифікації міжнародних угод та конвенцій стали першим кроком на шляху інтеграції транспортно-дорожнього комплексу України до міжнародної транспортної системи. Цьому також сприяє географічне положення України на перехресті доріг з Європи до Азії, а також завантаженість європейських транспортних вузлів. Українські залізниці безпосередньо межують і взаємодіють із залізницями Росії, Білорусі, Молдови, Польщі, Румунії, Словаччини, Угорщини й забезпечують роботу із сорока міжнародними залізничними переходами, а також обслуговують 18 українських морських портів Чорноморсько-Азовського басейну. Дві третини українських залізничних ліній $\epsilon$ вантажонапруженими, сучасними засобами керування, диспетчерською централізацією й автоблокуванням.

Міжнародні перевезення зростають швидше, ніж внутрішні, оскільки транзитні маршрути стають більш протяжними i перетинають все більше кордонів, але все ж таки діюча система перевезень в умовах перебудови економіки вимагають принципових змін 3 метою забезпечення високої швидкості руху поїздів і скорочення часу доставки вантажів і пасажирів[1].

Постановка наукової проблеми. Транспортні комунікації та світова інформаційна мережа $\epsilon$ «кровоносними судинами» світового господарства. Інформаційні технології сьогодні - це не просто засіб підтримки управління, а один із основних елементів інфраструктури залізничного транспорту[2].

Поряд 3 розвитком інфраструктури важливе значення має розширення інформаційного забезпечення усього транспортно-технологічного комплексу для задоволення жорстким вимогам по строкам доставки, збереженню вантажів і безпеки транспортування, удосконаленню та спрощенню прикордонних i митних процедур.

Загальною метою, що досягається у результаті рішення даної задачі, повинно бути прискорення обробки поїздів та підвищення пропускної спроможності станцій за рахунок зменшення часу на комерційний i технічний огляд поїздів, a також на операції, що проводяться органами державного контролю (митним, прикордонним і ін.). Регламент їх виконання в значній мірі залежать від розвитку технологій та засобів електронного обміну даними, що забезпечують інформаційне супроводження перевезень вантажів в міжнародному сполученні. Система електронного обміну даними повинна відповідати міжнародній транспортній інфраструктурі, базуватися на узгоджених технічних параметрах i задовольняти потреби сумісності технологій перевезень як критерій інтеграції національної транспортної системи в світову систему[3]. 
Мета статті. Дослідити особливості та можливості удосконалення експлуатаційної роботи залізничних станцій в умовах інформатизації, що дозволить зменшити час обробки та простою транзитних вагонів на станціях, в масштабах залізниці збільшити навантаження та вагонопотік між державами, відкрити нові коридори, що забезпечить підвищення рівня попиту на залізничні перевезення та ефективну роботу залізничного транспорту в міжнародному сполученні.

Основна частина. Причини, що викликають затримку вантажів:

a) завантаженість митних органів та затримка, що виникає у зв'язку з цим, в транзитному оформленні вантажів;

б) завантаженість станції через велике накопичення вантажу;

в) відсутність залізничного рухомого складу;

г) відсутність чи некомплектність вантажосупровідних документів, чи наявність документів, що не відповідають вимогам законодавства, невірно оформлені документи;

д) незлагодженість між вантажовласником, генеральним

експедитором, залізницею, що впливає на документообіг;

е) незлагодженість в роботі між прикордонною передаючою та приймаючою стороною[4].

Для моделювання процесу формування маршрутних поїздів розглянемо загальний випадок, коли між джерелом постачання вагонів (митні органи та ін ) розміщуються технологічні операції. Для кожної станції, після визначення строків постачання вагонів та вантажів, формується задача організації маршрутного поїзда 3 обліком часу та технологічних схем митного огляду, роботи в регіоні прикордонних та сортувальних станцій. У загальному виді час знаходження вагонів та вантажів на станції до закінчення формування маршрутного поїзда визначається на основі збору статистичного матеріалу та його обробки математичними методами.

В загальному ланцюгу операцій по обробці поїзда на виконання операцій по комерційному, технічному, прикордонномитних операцій витрачається близько $30 \%$ часу.

Облік вагоно-годин у транспортнологістичній системі для вагонів, визначено за формулою:

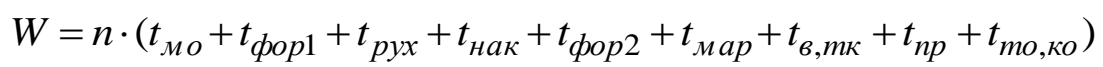

де $\mathrm{n}$ - кількість вагонів, що поступають на станцію для митного огляду;

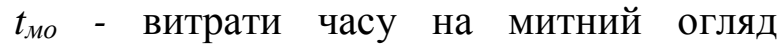
составів (операції проводяться паралельно 3 ТО та КО), 90 хв.;

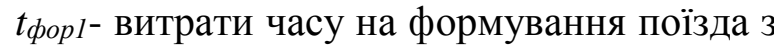
обліком простою під накопиченням на станції;

$t_{p y x}$ - час руху від прикордонної станції до станції формування транзитного поїзда;

$t_{\text {нак }}$ - витрати часу на накопичення вагонів на станції ;

$t_{\phi о р 2}$ - витрати часу на формування та очікування нитки графіку;

$t_{\text {мар }}$ - витрати часу на формування та транспортування до станції розформування маршруту;

$t_{\theta, m \kappa}$ - витрати часу на виконання операцій обробки перевізних документів в товарній конторі; $t_{n p}$ - час на операції по прийманню, 5 хв.;

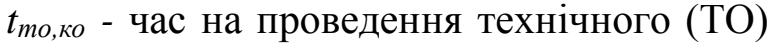
та комерційного огляду (КО) составу,45 хв. $[5,6]$.

Найсучаснішою

розробкою українських вчених залишається програма АСК ВП УЗ - $С$ (автоматизована система керування вантажними перевезеннями УЗ єдина). Основними перевагами цієї системи $€$ : оперативність надходження інформації, яка веде за собою значну економію часу на переробку та аналіз документації, надійність безперебійного забезпечення даними, можливість не тільки приймати та передавати інформацію, а й аналізувати, осмислювати, узагальнювати ii та автоматично формувати довідки та інші переваги. На автоматизованих робочих місцях станційних працівників передбачено підготовку й передачу інформації до бази 
даних «АСК ВП УЗ-С» про всі технологічні операції 3 поїздами, вагонами, контейнерами, локомотивами, а також про роботу окремих ділянок та підрозділів станції. «АCK ВП УЗдотримання логічної послідовності технологічних операцій міжнародних вантажних перевезень. Для досягнення цих задач доцільно організувати удосконалення впровадженої підсистеми АРМ логіста. Важливим засобом підвищення ефективності роботи залізничної станції $є$ застосування методів на базі інформаційно-керуючих систем (ІКС) i технологій. Переваги від застосування ІІКС $є$ : - оптимізація у реальному часі управлінських рішень 3 організації технологічних процесів спрямованих на мінімізацію витрат; збільшення доходів за рахунок використання маркетингових досліджень; - підвищення рівня рентабельності та максимізація прибутку. Стратегія реалізується при наявності таких функцій: - формування необхідної інформації для «АСК ВП УЗ-С»; оперативний контроль та аналіз процесу обробки експортно-імпортного вагонопотоку на прикордонній вантажній станції; економічна оцінка варіантів оперативних планів організації роботи станцій (за допомогою системи підтримки прийняття рішень); - контроль просування транспортного потоку за допомогою датчиків на вагонах із дотриманням технологічних норм на виконання операцій; прогнозування змін в оперативній ситуації на станції; - контроль за обсягом передачі вагонів через кордон; - прийняття рішень щодо керуючого впливу на перевізний процес на прикордонній вантажній станції; контроль за виконанням вантажних операцій як на під’їних коліях, а також формуванням оптимальних партій вантажів та вагонів у АРМ логіста. При формуванні IКС АРМ логіста 3 впровадженням GPS-моніторингу центральною частиною залишається вирішення задач планування, прогнозу й аналізу експлуатаційної роботи залізничної станції. До ІКС залізничної станції входить значна кількість АРМів. Кожне АРМ має доступ до потрібної інформації про стан перевізного процесу відповідно до статусу користувача та обсягу роботи, яку він виконує. При формуванні удосконаленої структури IКС потрібно врахувати зв'язки між АРМ працівників станції та автоматизованими системами різних рівнів та обмін інформацією між ними. Провадження лінії інформаційного обміну між АРМ логіста i «АСК ВП УЗ-С» дозволить працівнику контролювати переміщення вагонів, 3 можливими затримками i порушеннями, отримувати інформацію щодо транзитних та імпортних вагонопотоків для попереднього оформлення митних декларацій. Таке впровадження сприятиме зменшенню простоїв вагонів на залізничних станціях. Ще одна система, на яку покладається цілий комплекс технологічних завдань від розрахунку раціонального режиму ведення поїзда до контролю використання палива, - це система AC «Навігація. Інформація. Управління» «НІУ». Однією 3 важливих складових, що забезпечує вирішення комплексу технологічних завдань, $\epsilon$ можливість системи безперервно визначати координатне місцезнаходження одиниці рухомого складу, на яку встановлено відповідний датчик. Тим самим надається об'єктивна картинка дислокації рухомої одиниці. Системою «АСК ВП УЗ - С» дислокація поїзда, як сума декількох одиниць рухомого складу, визначається дислокацією локомотива (його номерами) у складі поїзда. Але ідентифікація складу одиниць (кількість та номери вагонів) у поїзді визначається оператором i формується за регламентом ручного уведення їх номерів у систему «АСК ВП УЗЄ» [7].

Висновки з дослідження i
перспективи, подальший розвиток у
даному напрямку. При використанні даних
системи залізниця отримує для себе низку
переваг таких як зниження експлуатаційних
витрат на перевезення за рахунок:-
зменшення трудових затрат на підготовку,
передачу, обробку перевізних документів
при міжнародних перевезеннях вантажів ,
разом з транзитними перевезеннями;-
зниження затрат на передавання даних про
місцезнаходження, підході, стан вантажу;--
зменшення втрати часу, що пов'язані 3


очікуванням обробки перевізних документів та виконання митних процедур при перетинанні межі в пунктах пропуску;покращення використання транспортних засобів та транспортного обладнання (приклад: зменшення випадків повернення через недостовірну інформацію); зменшення випадків втрати вантажів, роз'єднання вантажів та документів на них[8].

Отримання додаткового прибутку за рахунок: - розширення транспортних послуг та застосування сучасних транспортних технологій

та інформаційного забезпечення; - організація додаткових інформаційних послуг власникам вантажів, експортерам та імпортерам по спостеріганню за процесом перевезення.

Мінімізація втрат від відпущеного прибутку шляхом інформаційної взаємодії 3 партнерами та іншими учасниками перевезення вантажів в міжнародному повідомленні на основі застосування даних програм, підвищення оперативності реагування на зміни ситуації та кон'юнктури[9].

\section{Список використаних джерел}

1. О.А. Чуйко Розвиток міжнародних перевезень на українських залізницях [Текст] / О.А. Чуйко // : зб. наук. пр. / Укр. держ. акад. залізнич. трансп. - Х., 2010. - Вип. 119. - С. 20-22.

2. Зябиров Х.Ш «Развитие электронного документооборота при перевозках грузов в международном сообщении». [Текст] / Зябиров Х.Ш // Железнодорожній транспорт 2005 №7 - C. $12-14$.

3. Елисеев С.Ю. Логистические технологии в управлении грузовыми перевозками через пограничные переходы [Текст] / Елисеев С.Ю..// Ж.-Д. транспорт. № 7. 2006.- С 40-43

4. Орлова В.Г. Перевозка грузов в международном железнодорожном сообщении. [Текст]/ Орлова В.Г.// Под. ред.: Транспорт, 1983. 163 с.

5. Сычев А.Е Підвищення ефективності перевезень вантажів в міжнародному сполученні на основі принципів логістики [Текст]: автореф. дис. д-ра екон. наук : 25.04.2007 / Сичев А. Е. .-М ., 2007 .-30 с.

6. Елисеев С.Ю., К технологии логистических центров [Текст]: підруч. / Елисеев С.Ю., Котляренко А.Ф., Куренков П.В.. // Логистика. № 3. 2003. С. 5364.

7. Д.С. Кравченко Удосконалення вантажних перевезень у міжнародному сполученні на основі автоматизації оперативного управління [Текст]: / Д.С. Кравченко // : зб. наук. пр. / Укр. держ. акад. залізнич. трансп. . - Х., 2014 №146.- С 86-90

8. Галабурда В.Г. Оптимальное планирование грузопотока. [Текст]/ Галабурда В.Г. .// Под. ред.: М.: Транспорт, 1985.256 с.

9.Дерибас А.Т. Организация грузовой и коммерческой работы на железнодорожном транспорте. [Текст] : навч. посіб. / Дерибас А.Т., Повороженко В.В., Потапов В.П. ;М.: Транспорт. 1970. 311с.

Рецензент д-р техн. наук, професор О.М.Огар

Редина Дина Александровна, магістр $а н т$ E-mail :redinadina@yandex.ru

Лавріненко Тетяна Михайловна,магістрант E-mail :tasyayo@email.ua

Redina Dina Aleksandrovna , Master's Student E-mail :redinadina@yandex.ru

Lavrinenko Tatyana Mikhailovna, Master's Student E-mail :tasyayo@email.ua 